\title{
Evaluation of parasite and host phenolic composition and bioactivities - The Practical Case of Cytinus hypocistis (L.) L. and Halimium lasianthum (Lam.) Greuter
}

\author{
Ana Rita Silva ${ }^{\mathrm{a}, \mathrm{b}}$, Manuel Ayuso ${ }^{\mathrm{a}}$, Carla Pereira ${ }^{\mathrm{a}}$, Maria Inês Dias ${ }^{\mathrm{a}}$, Marina Kostić ${ }^{\mathrm{c}}$, \\ Ricardo C. Calhelha $^{a}$, Marina Sokovic ${ }^{c}$, Pablo A. García ${ }^{b}$, Isabel C.F.R. Ferreira ${ }^{a}$, \\ Lillian Barros ${ }^{\mathrm{a}, *}$ \\ ${ }^{a}$ Centro de Investigação de Montanha (CIMO), Instituto Politécnico de Bragança, Campus de Santa Apolónia, 5300-253 Bragança, Portugal \\ b Departamento de Ciencias Farmacéuticas. Facultad de Farmacia, CIETUS-IBSAL, Universidad de Salamanca, 37007 Salamanca, España

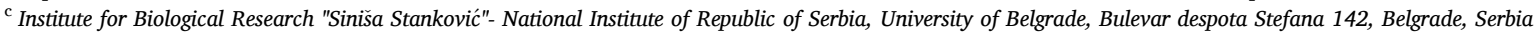

\section{A R T I C L E I N F O}

\section{Keywords:}

Tannins

Flavonoids

Antioxidant

Antimicrobial

Cytotoxicity

Tyrosinase inhibition

\begin{abstract}
A B S T R A C T
Cytinus hypocistis (L.) L. is a comestible holoparasite with great potential for cosmeceutical application. Although its high tannin content has been associated with its bioactive and inhibitory enzyme properties, this is the first report establishing a relationship between parasite and host (Halimium lasianthum (Lam.) Greuter) phenolic profile and bioactive properties. Thus, five extracts (aerial and root extracts of non-parasited and parasited H. lasianthum and C. hypocistis) were evaluated. The tentative identification of both species comprises 39 phenolic compounds. Hydrolysable tannins and flavonoids were the main identified groups in C. hypocistis and H. lasianthum extracts, respectively. Regarding bioactivities, C. hypocistis exhibited excellent antioxidant results both in Oxidative Haemolysis (OxHLIA) and inhibition of Thiobarbituric Acid Reactive Substances Formation (TBARS). The tested extracts presented antimicrobial inhibition, anti-inflammatory activity, and effective cytotoxicity against tumour cells. C. hypocistis exhibited the lowest cytotoxicity on a non-tumour cell line. Principal Component Analysis (PCA) was a suitable approach to analyse differences among samples, explaining up to $67 \%$ of data variability and suggesting no similarities between parasite and host phenolic composition and bioactivities. Therefore, this comparative study emphasises the significance of both species as a source of biologically active compounds.
\end{abstract}

\section{Introduction}

Parasitism is an effective strategy exhibited by living organisms and an area that connects all Kingdoms of life (Westwood et al., 2010). Parasite-host relationships are usually not arbitrary and relatively stable, indicating a long evolutionary history (de Vega et al., 2008). In the specific case of plants, these associations are characterised by the ability to obtain resources from another plant through a direct physical connection, invading both the roots or the shoots of the hosts via specific structures (haustorium) (Westwood et al., 2010). Host dependency level varies and can be classified according to their photosynthetic status. Hemiparasites are photosynthetically auto sufficient; they parasite to obtain non-photosynthetic nutrients and water. Contrarily, holoparasites lack chlorophyll and photosynthesis; therefore, the carbon, water, and other nutrients must be obtained from the host (Rubiales and Heide-Jørgensen, 2011).

Cytinus hypocistis (L.) L. is a holoparasite in which the vegetative body is reduced to an endophytic structure that develops inside the host roots (de Vega et al., 2008; Sanjust and Rinaldi, 2021). Concerning its ethnobotanical uses, this parasite was applied to treat intestinal problems, inflammation, specific tumours, and haemorrhages (Zucca et al., 2015). This parasitic plant is only visible during the flourishing season, with flowerings breaking through the host (Zucca et al., 2015). Although this genus was long contemplated within the family Rafflesiaceae, phylogenetic analyses and variations in flowers morphology, ovaries, and seeds, recognised Cytinus as a member of the Cytinaceae family (Bouman and Meijer, 1994; de Vega et al., 2008). Europe has two documented species of Cytinus: Cytinus hypocistis and Cytinus ruber, the

\footnotetext{
* Corresponding author.

E-mail address: lillian@ipb.pt (L. Barros).
} 
first has yellowish flowers while the second has ivory-white to rose-pink (Sanjust and Rinaldi, 2021; Silva et al., 2019; Zucca et al., 2015). Cytinus hypocistis (L.) L. can be further classified into four subspecies: hypocistis, clusii Nyman, lutescens (Batt.) Maire, and macranthus Wettst. Variances between subspecies are very difficult to detect, mainly laying in flowerings colour and host identity. The subspecies macranthus Wettst, which was used in the present work, has characteristic large bright yellow flowers and was only described as a parasite on plants from the Halimium genus (de Vega et al., 2008; De Vega et al., 2007; Sanjust and Rinaldi, 2021). The genus Halimium belongs to the Cistaceae family; it comprises thirteen accepted evergreen or semi-deciduous small-to-large shrubs species and occupies a specific niche in the Mediterranean biome, with an increasingly appreciated ecological function. Improves the water and light regime, protects soil from erosion and desertification, and acts as "nurse" species for tree seedlings (Leonardi et al., 2020). Although, to date, most studies on plant parasitism were focused on nutrient transfer, a growing number of studies have recognised the transference of non-nutrient molecules. The transference of phytohormones, secondary metabolites, RNAs, and proteins suggests that hosts may significantly impact parasite physiology and ecology, essential processes for development and plant defence (Smith et al., 2013).

Recent studies pointed to $C$. hypocistis as a potential source of biologically active compounds with cosmeceutical interest (Maisetta et al., 2019; Silva et al., 2021a; Zucca et al., 2015). Although its high tannin content has been correlated to its bioactivities, no studies on the host phytochemical profile have been performed. Thus, the present study main objective was to evaluate $H$. lasianthum phenolic composition and bioactive properties and its possible influence on the parasite C. hypocistis. This study will bring new insights regarding host bioactive potential and parasite-host interactions.

\section{Material and methods}

\subsection{Plant material and extracts preparation}

The parasitic plant $C$. hypocistis and the two forms (parasited and non-parasited) of the host species H. lasianthum (Fig. 1) were collected in July 2020 at different locations in Castro Daire, Viseu, Portugal. Samples processing was directed as formerly detailed (Silva et al., 2019). The extracts were prepared using Heat-Assisted Extraction (HAE) at the optimum global condition determined during previous work; the samples $(0.8 \mathrm{~g})$ were mixed with a hydroethanolic solution $(40 \mathrm{~mL} ; 95.1$ $\min , 46.4{ }^{\circ} \mathrm{C}$, and $74.3 \%$ ). The mixture was extracted in a water bath, as previously described (Silva et al., 2021a). A total of five hydroethanolic extracts were prepared: the whole $C$. hypocistis (CH); parasited $H$. lasianthum aerial parts (PHLAP); parasited H. lasianthum roots (PHLR); non-parasited H. lasianthum aerial parts (HLAP); and non-parasited H. lasianthum aerial roots (HLR).

\subsection{Phenolic profile determination}

The freeze-dried extracts were redissolved in a hydroethanolic solution $\left(5 \mathrm{mg} \mathrm{mL}^{-1} ; 20 \%\right)$. Phenolic compounds were analysed by HPLCDAD-ESI/MS ${ }^{\mathrm{n}}$ as formerly described by Bessada and colleagues (Bessada et al., 2016). The UV spectra, fragmentation pattern, retention time were used for phenolic compound tentative identification when no standards were available. The commercial standards used for quantification were: gallic acid; ellagic acid; apigenin-6-C-glucoside; catechin; chlorogenic acid; naringenin; quercetin-3-O-glucoside; taxifolin; and $p$-coumaric acid. Their calibration curve, limit of detection (LOD), and limit of quantification (LOQ) are presented in Table 1. Compound quantification was presented as $\mathrm{mg} \mathrm{g}^{-1}$ extract.

\subsection{Evaluation of the bioactivities}

\subsubsection{Antioxidant activities}

The inhibition of thiobarbituric acid reactive substances formation (TBARS) and oxidative haemolysis (OxHLIA) were evaluated. The positive control of both methods was the water-soluble vitamin $\mathrm{E}$ analogue, Trolox. Briefly, in the OxHLIA method, $200 \mu \mathrm{L}$ of an erythrocyte solution were incubated with either $400 \mu \mathrm{L}$ of extracts ( $900 \mu \mathrm{g} \mathrm{mL}^{-1}$ in PBS), PBS or milli-Q water. After preincubation at $37{ }^{\circ} \mathrm{C}$, AAPH was mixed, and the optical density $(690 \mathrm{~nm})$ was measured until complete haemolysis $(\Delta t$ : $60 \mathrm{~min}$ ) (Lockowandt et al., 2019). Succinctly, in the TBARS method, a pig brain homogenate was used to analyse the capacity of the different extract concentrations to inhibit the malondialdehyde (MDA) complexes formation (optical density measured at $532 \mathrm{~nm}$ ), as comprehensibly described by Silva and colleagues (A. R. V. Silva et al., 2020; A.R. Silva et al., 2020). The results for both methods were presented as $\mathrm{IC}_{50}: \mu \mathrm{g}$ $\mathrm{mL}^{-1}$.

\subsubsection{Tyrosinase inhibitory activity}

The inhibition of tyrosinase activity was evaluated as formerly described by Moonrungsee and colleagues (Moonrungsee et al., 2012). Four concentrations $\left(2.5,1.25,0.625\right.$, and $\left.0.3125 \mathrm{mg} \mathrm{mL}^{-1}\right)$ of each extract were dissolved in a $50 \%$ hydroethanolic solution. $10 \mu \mathrm{L}$ of each concentration was added to the correspondent wells (three per concentration), followed by $100 \mu \mathrm{L}$ of $2.0 \mathrm{mM} \mathrm{L}-\mathrm{DOPA}$, and $10 \mu \mathrm{L}$ of tyrosinase (142 units $\mathrm{mL}^{-1}$ ) resuspended in $180 \mu \mathrm{L}$ of $0.1 \mathrm{M}$ phosphate buffer ( $\mathrm{pH}$ 6.8), performing a final volume of $300 \mu \mathrm{L}$. The microplate was incubated for $10 \mathrm{~min}$ (room temperature) and measured at $575 \mathrm{~nm}$ using a 96-well plate microplate reader (BMG Labtech, Germany). Kojic acid (1.5, 3, and $6 \mathrm{mM})$ was the selected positive inhibitor (control). The

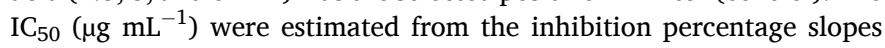
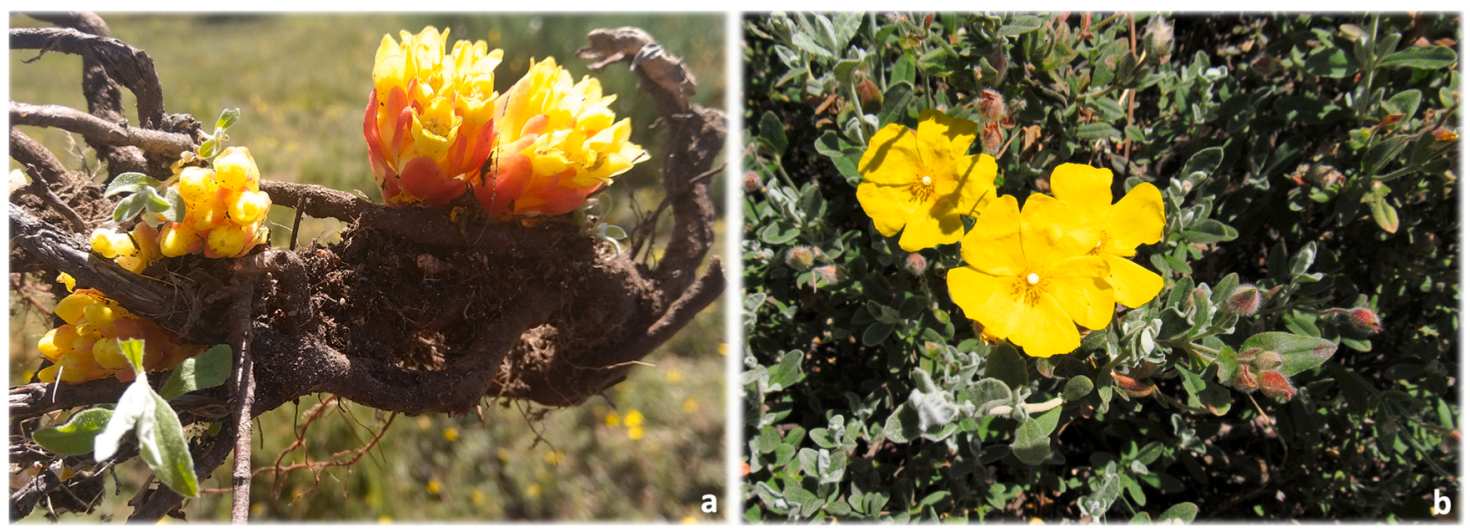

Fig. 1. (a) Multiple inflorescences of the parasitic plant Cytinus hypocistis (L.) L. subsp. macranthus Wettst growing on the roots of a single host. (b) Plant host: Halimium lasianthum subsp. alyssoides (Lam.) Greuter. 
Table 1

Phenolic compounds identification and quantification in H. lasianthum and C. hypocistis extracts.

\begin{tabular}{|c|c|c|c|c|c|c|c|c|c|c|}
\hline \multirow[t]{3}{*}{ Peak } & \multirow{3}{*}{$\begin{array}{c}\mathrm{Rt} \\
(\mathrm{min})\end{array}$} & \multirow{3}{*}{$\begin{array}{l}\lambda_{\max } \\
(\mathrm{nm})\end{array}$} & \multirow{3}{*}{$\begin{array}{c}{[\mathrm{M}-\mathrm{H}]^{-}(m /} \\
z)\end{array}$} & \multirow[t]{3}{*}{$\mathrm{MS}^{2}(m / z)$} & \multirow[t]{3}{*}{ Tentative identification } & \multicolumn{5}{|c|}{ Content (mg g ${ }^{-1}$ extract) } \\
\hline & & & & & & \multicolumn{2}{|c|}{ Non-parasited H. lasianthum } & \multicolumn{2}{|c|}{ Parasited $H$. lasianthum } & \multirow{2}{*}{$\begin{array}{l}\text { C. hypocistis } \\
\mathrm{CH}\end{array}$} \\
\hline & & & & & & HLR & HLAP & PHLR & PHLAP & \\
\hline 1 & 3.60 & 275 & 331 & 169(100), 125(9) & Galloyl-glucose $^{1}$ & nd & nd & nd & nd & $0.512 \pm 0.004$ \\
\hline 2 & 4.03 & 275 & 483 & $331(100), 169(13)$ & Digalloyl-glucose $^{1}$ & nd & nd & nd & nd & $3.5 \pm 0.2$ \\
\hline 3 & 4.51 & 259 & 1083 & 781(86), 721(21), 601(100), 575(25) & Punicalagin isomer $^{2}$ & nd & $7.4 \pm 0.3$ & nd & $7.8 \pm 0.1$ & nd \\
\hline 4 & 5.31 & 259 & 1083 & $\begin{array}{c}\text { 1065(5), 785(62), 763(5), } 721(23), 601 \\
\text { (100) }\end{array}$ & Gallagyl ester $^{1}$ & nd & $8.0 \pm 0.3$ & nd & $11.3 \pm 0.3$ & nd \\
\hline 5 & 5.47 & 275 & 635 & 483(40), 465(100), 421(10), 313(5) & Trigalloyl-glucoside $^{1}$ & nd & nd & nd & nd & $1.77 \pm 0.09$ \\
\hline 6 & 5.55 & 260 & 593 & 503(2), 473(100), 431(2), 311(1) & Apigenin-C-dihexoside ${ }^{3}$ & nd & nd & $0.0103 \pm 0.0003$ & nd & nd \\
\hline 7 & 6.14 & 278 & 289 & 245(100), $203(8)$ & $(+)$-Catechin ${ }^{4}$ & nd & nd & nd & nd & $2.23 \pm 0.09$ \\
\hline 8 & 6.20 & 376 & 1085 & $\begin{array}{c}\text { 781(100), 721(13), 601(99), 575(23), } 549 \\
(18)\end{array}$ & Digalloyl-gallagyl-hexoside $^{1}$ & nd & $3.2 \pm 0.1$ & nd & $3.2 \pm 0.1$ & nd \\
\hline 9 & 6.35 & 325 & 353 & 191(100), 179(6), 173(1), 161(1), 135(0.2) & 5-O-Caffeoylquinic acid ${ }^{5}$ & $1.87 \pm 0.01$ & nd & nd & nd & nd \\
\hline 10 & 8.09 & 275 & 635 & $\begin{array}{c}\text { 483(21), 465(100), 421(1), 313(1), } 169 \\
\text { (25) }\end{array}$ & Trigalloyl-glucoside $^{1}$ & nd & nd & nd & nd & $0.46 \pm 0.02$ \\
\hline 11 & 9.33 & $\begin{array}{l}217 / \\
317\end{array}$ & 421 & 403(17), 331(89), 301(100), 259(1) & Mangiferin $^{6}$ & $0.059 \pm 0.002$ & nd & nd & nd & nd \\
\hline 12 & 11.88 & 352 & 611 & 593(16), 317(100), 271(14) & Myricetin 3-O-arabinogalactoside $^{7}$ & nd & $1.078 \pm 0.004$ & nd & $1.2257 \pm 0.0001$ & nd \\
\hline 13 & 12.84 & 350 & 465 & 447(57), 437(68), 303(43), 285(100), 259 & Taxifolin-O-hexoside ${ }^{8}$ & $0.250 \pm 0.002$ & nd & $0.222 \pm 0.002$ & nd & nd \\
\hline 14 & 13.36 & 338 & 431 & 341(4), 311(100), 283(3) & Apigenin- $C$-hexoside ${ }^{3}$ & nd & nd & $0.182 \pm 0.004$ & nd & nd \\
\hline 15 & 13.90 & 277 & 937 & 785(64), 767(100), 465(70), 301(94) & Trigalloyl-HHDP-glucoside ${ }^{2}$ & nd & $3.0 \pm 0.1$ & nd & nd & $5.4 \pm 0.1$ \\
\hline 16 & 14.18 & 354 & 479 & $461(3), 316(100), 317(87)$ & Myricetin-O-hexoside $^{7}$ & nd & $1.23 \pm 0.01$ & nd & $1.15 \pm 0.01$ & nd \\
\hline 17 & 14.34 & 275 & 787 & 635(25), 617(100), 465(5) & Tetragalloyl-glucoside $\mathrm{I}^{1}$ & nd & nd & nd & nd & $6.6 \pm 0.2$ \\
\hline 18 & 15.40 & 275 & 787 & 635(25), 617(100), 465(5) & ${\text { Tetragalloyl-glucoside } \text { II }^{1}}$ & nd & nd & nd & nd & $2.3 \pm 0.1$ \\
\hline 19 & 15.64 & 275 & 787 & 635(25), 617(100), 465(5) & Tetragalloyl-glucoside $\mathrm{III}^{1}$ & nd & nd & nd & nd & $8.5 \pm 0.1$ \\
\hline 20 & 16.33 & 351 & 463 & $316(100), 317(62)$ & Myricetin-O-rhamnoside ${ }^{7}$ & nd & $4.7 \pm 0.2$ & nd & $3.829 \pm 0.009$ & nd \\
\hline 21 & 17.22 & 357 & 463 & $301(100)$ & Quercetin-O-hexoside ${ }^{7}$ & $1.028 \pm 0.002$ & nd & nd & nd & nd \\
\hline 22 & 17.55 & 352 & 463 & $317(42), 316(76), 301(100)$ & Quercetin-3-O-glucoside ${ }^{7}$ & $1.022 \pm 0.001$ & $1.146 \pm 0.002$ & nd & $1.115 \pm 0.005$ & nd \\
\hline 23 & 17.90 & 275 & 939 & 787(50), 769(100), 617(10), 599(5) & Pentagalloyl-glucoside ${ }^{1}$ & nd & nd & nd & nd & $10.4 \pm 0.5$ \\
\hline 24 & 18.30 & 278 & 935 & $783(100), 765(13), 633(5), 301(5)$ & Galloyl-bis-HHDP-glucose I ${ }^{2}$ & nd & nd & nd & nd & $26 \pm 1$ \\
\hline 25 & 19.06 & $\begin{array}{l}272 / \\
353\end{array}$ & 505 & 463(23), $301(100)$ & Quercetin-O-acetylhexoside $^{7}$ & nd & $2.495 \pm 0.005$ & nd & $1.010 \pm 0.004$ & nd \\
\hline 26 & 20.03 & 354 & 433 & $342(2), 307(1), 301(100)$ & Quercetin-O-pentoside $^{7}$ & nd & $0.987 \pm 0.002$ & nd & $1.024 \pm 0.005$ & nd \\
\hline 27 & 20.31 & 353 & 491 & $315(100)$ & Isorhamnetin-O-glucuronide $^{7}$ & nd & nd & nd & $1.16 \pm 0.01$ & nd \\
\hline 28 & 20.48 & 353 & 771 & $\begin{array}{c}551(51), 533(59), 463(16), 317(100), 265 \\
(48)\end{array}$ & $\begin{array}{l}\text { Myricetin-O-coumaroyl-deoxyhexoside- } \\
\text { hexoside }^{7}\end{array}$ & nd & $1.000 \pm 0.004$ & nd & nd & nd \\
\hline 29 & 20.72 & 278 & 935 & 783(100), 765(15), 633(8), 301(7) & Galloyl-bis-HHDP-glucose II $^{2}$ & nd & nd & nd & nd & $9.4 \pm 0.4$ \\
\hline 30 & 20.92 & 348 & 447 & 429(2), 343(1), 327(1), 301(100), 285(5) & Quercetin-3-O-rhamnoside ${ }^{7}$ & nd & $1.13 \pm 0.01$ & nd & $1.204 \pm 0.002$ & nd \\
\hline 31 & 20.98 & 277 & 581 & $535(100), 355(21)$ & $p$-Coumaroyl-monotropein derivative ${ }^{9}$ & $0.315 \pm 0.005$ & nd & $0.141 \pm 0.007$ & nd & nd \\
\hline 32 & 21.44 & 278 & 1087 & 935(100), 783(20), 633(3), 301(11) & Digalloyl-bis-HHDP-glucose $\mathrm{I}^{2}$ & nd & nd & nd & nd & $7.31 \pm 0.07$ \\
\hline 33 & 23.02 & 277 & 1087 & 935(100), 783(18), 633(5), 301(14) & Digalloyl-bis-HHDP-glucose $\mathrm{II}^{2}$ & nd & nd & nd & nd & $8.6 \pm 0.1$ \\
\hline 34 & 23.76 & 278 & 1087 & 935(100), 783(18), 633(5), 301(14) & Digalloyl-bis-HHDP-glucose $\mathrm{III}^{2}$ & nd & nd & nd & nd & $3.32 \pm 0.01$ \\
\hline 35 & 25.53 & 277 & 1257 & $\begin{array}{c}\text { 1087(100), 935(66), 783(15), 633(5), } 301 \\
\text { (12) }\end{array}$ & Trigalloyl-bis-HHDP-glucose $\mathrm{I}^{2}$ & nd & nd & nd & nd & $5.9 \pm 0.3$ \\
\hline 36 & 26.77 & 277 & 1257 & $\begin{array}{c}\text { 1087(100), 935(55), 783(13), 633(5), } 301 \\
\text { (10) }\end{array}$ & Trigalloyl-bis-HHDP-glucose $\mathrm{II}^{2}$ & nd & nd & nd & nd & $2.9 \pm 0.1$ \\
\hline 37 & 27.10 & 346 & 1187 & 901(68), 635(11), 593(100), 447(5) & Kaempferol-coumaroyl-hexoside ${ }^{7}$ & nd & $0.976 \pm 0.005$ & nd & $0.996 \pm 0.001$ & nd \\
\hline 38 & 31.70 & $\begin{array}{l}269 / \\
332\end{array}$ & 593 & 575(1), 447(13), 327(1), 307(7), 285(100) & $\begin{array}{l}\text { Kaempferol-O-rhamnoside-O-hexoside }{ }^{7} \\
\text { Kaempferol-coumaroyl-hexoside }\end{array}$ & nd & $1.122 \pm 0.006$ & nd & $1.001 \pm 0.004$ & nd \\
\hline
\end{tabular}




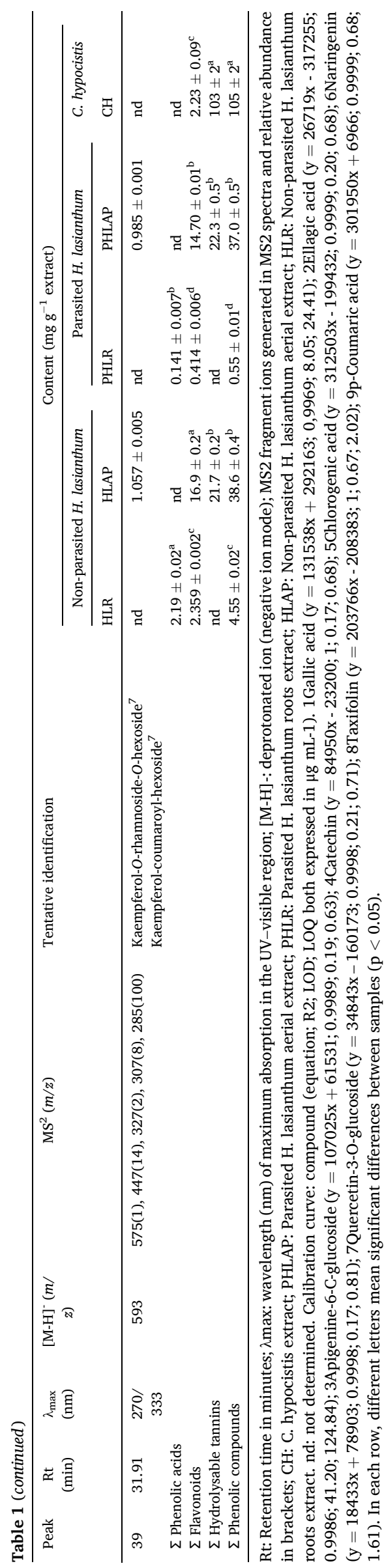

using GraphPad Prism 9 (GraphPad Prism 9.1.1 for macOS, 2021 GraphPad Software, LLC.).

\subsubsection{Antiproliferative and cytotoxic activity}

The extracts were redissolved ( $8 \mathrm{mg} \mathrm{mL}^{-1}$ ), subjected to consecutive dilutions $\left(6.25-400 \mu \mathrm{g} \mathrm{mL}^{-1}\right)$, and tested against 4 tumour and 1 nontumour cell line. The tumour cultures were obtained from the LeibnizInstitut DSMZ: AGS, Caco-2, MCF-7, and NCI-H460 (Pantuzza Silva et al., 2021; A. R. A.R. Silva et al., 2020; V. Silva et al., 2020). Regarding non-tumoral cells, a kidney epithelial cell line of an African green monkey (VERO - ECACC) was used. Cell density was determined using the sulforhodamine B method, with ellipticine as the positive control (Guimarães et al., 2013a). The results were expressed as the sample concentrations required to inhibit $50 \%$ of the cell growth $\left(\mathrm{GI}_{50}: \mu \mathrm{g}\right.$ $\left.\mathrm{mL}^{-1}\right)$.

\subsubsection{Anti-inflammatory activity}

This activity was evaluated in macrophages (RAW 264.7), as formerly described by Silva and colleagues (A. R. A.R. Silva et al., 2020; V. Silva et al., 2020). Briefly, the method measures the inhibition of lipopolysaccharides-stimulated NO formation after incubation with the tested five extracts $\left(6.25-400 \mu \mathrm{g} \mathrm{mL}^{-1}\right)$. NO formation was estimated using the Griess Reagent System kit Promega, the dexamethasone as a positive control, and the cells with no lipopolysaccharides added as the negative control (Souilem et al., 2017). The results were presented as extract concentration offering $50 \% \mathrm{NO}$ inhibition $\left(\mathrm{IC}_{50}: \mu \mathrm{g} \mathrm{mL} \mathrm{m}^{-1}\right.$ ).

\subsubsection{Antimicrobial activity}

Different concentrations $\left(0.1-20 \mathrm{mg} \mathrm{mL}^{-1}\right)$ of the five extracts were tested for antibacterial and antifungal activity against several microorganisms deposited at the University of Belgrade. As previously described, 3 Gram + bacteria: Staphylococcus aureus, Bacillus cereus, and Listeria monocytogenes, and three Gram- bacteria: Escherichia coli, Salmonella Typhimurium, and Enterobacter cloacae were used to assess the antibacterial potential of the extracts (Heleno et al., 2013). Additionally, the activity against 6 micromycetes was also evaluated: Aspergillus fumigatus (human isolate), Aspergillus niger, Aspergillus versicolor, Penicillium funiculosum, Penicillium verrucosum var. cyclopium, and Trichoderma viride (Ayuso et al., 2020; Heleno et al., 2013). The positive controls used for antimicrobial and antifungal activity were streptomycin and ampicillin; and ketoconazole and bifonazole, respectively. The results were presented as the minimum concentration of extract (mg $\mathrm{mL}^{-1}$ ) required to inhibit the growth of the microbes (MIC) or to exert a bactericidal (MBC) and fungicidal (MFC) effect.

\subsection{Statistical analysis}

The experiments were executed in triplicate, except for the antimicrobial activity, and the results were tested to their normal distribution and homogeneity of variance. The statistical analyses were performed using GraphPad Prism (GraphPad Prism 9.1.1 for macOS, 2021 GraphPad Software, LLC.). Significant differences were evaluated by variance analysis (ANOVA) and Tukey's HSD test $(\alpha=0.05)$. The student's $t$-test was used when two independent groups were compared $(\alpha=0.05)$. Principal Component Analysis (PCA) was performed as a pattern recognition technique to distinguish samples according to their phenolic profile and bioactivities. For a better interpretation of PCA, data from antioxidant, tyrosinase inhibition, cytotoxicity against tumour cells, anti-inflammatory, and antimicrobial (average MIC for Gram+, Gram-, and Micromycetes) activities were reciprocally (inverse) transformed $\left(1 / \mathrm{IC}_{50}, 1 / \mathrm{GI}_{50}\right.$ or $\left.1 / \mathrm{MIC}\right)$ before analysis since in bioactivity assays a lower value means higher activity. PCA was performed on standardised data, and the selection of the principal components (PCs) was executed using the Kaiser rule (eigenvalues higher than 1). Two PCs were selected and plotted to improve interpretation. 


\section{Results and discussion}

\subsection{Phenolic profile determination}

Table 1 shows the data attained for the phenolic compounds tentative identification and quantification of $C$. hypocistis and $H$. lasianthum extracts. The obtained profiles included phenolic acids, flavonoids, and hydrolysable tannins.

\subsubsection{Phenolic acids}

Two hydroxycinnamic acids were identified in $H$. lasianthum root extracts. The 5-O-caffeoylquinic acid (Peak 9 ) was identified in the nonparasited $H$. lasianthum root extract (HLR) using a commercial standard and confirmed by its UV spectra and deprotonated ion ( $\lambda \max 325 \mathrm{~nm}$; $m / z$ 353) (Chihoub et al., 2019). The fragmentation pattern in $\mathrm{MS}^{2}$ gave a major ion at $m / z 191$, corresponding to the deprotonated quinic acid and a minor at $m / z 179$ [caffeic acid-H]'. Compound 31, present in the non-parasited (HLR) and parasited (PHLR) root extracts of $H$. lasianthum, was tentatively identified as a $p$-coumaroyl-monotropein derivative. It occurred as a formate adduct at $m / z 581$ rather than as a molecular ion at $m / z 535$, with a minor ion at $m / z 355$, consistent with the loss of p-coumaric acid ( $-164 \mathrm{u}$ ) and oxygen $(-16 \mathrm{u})$ (Heffels et al., 2017).

\subsubsection{Flavonoids}

A total of 18 flavonoids were tentatively identified: 4 flavones (peaks 6, 11, 14, and 27), 1 flavan-3-ol (peak 7), 1 flavanonol (peak 13), and 12 flavonols (peaks 12, 16, 20-22, 25, 26, 28, 30, and 37-39). Compounds 6 and 14 were tentatively identified as apigenin derivatives (PHLR extract). Apigenin- $C$-dihexoside (Peak 6) presented a deprotonated ion at $m / z 593$ and a major peak at $m / z 473[\mathrm{M}-\mathrm{H}-120]^{-}$, characteristic of di- $C$-glycosyl flavones. The $\mathrm{MS}^{\mathrm{n}}$ fragment at 311 indicated the loss of a hexosyl moiety [M-H- 162 $]^{-}$and the presence of apigenin (MW 270) as aglycone. Compound 14 gave a $[\mathrm{M}-\mathrm{H}]^{-}$ion at $m / z 431$, and its $\mathrm{MS}^{\mathrm{n}}$ spectrum yielded ions at $m / z 341[\mathrm{M}-\mathrm{H}-90]^{-}$and $311[\mathrm{M}-\mathrm{H}-120]^{-}$, thus being identified as apigenin- $C$-hexoside (García-Pérez et al., 2021). Compound 11 (HLR extract) was tentatively identified as mangiferin, a $C$-glycoside of monomeric xanthones with a pseudo-molecular ion at $m / z$ 421, showing two characteristic ions ([M-H-90 $]^{-}$and $[\mathrm{M}-\mathrm{H}-120]^{-}$) at $m / z 331$ and 301 , corresponding to the different parts of the glucose moiety in the $\mathrm{MS}^{2}$ analysis. The two minor ions at $m / z 403$ and 259 correspond to a typical loss of a water molecule $(-18 \mathrm{u})$ and a fragment of the glucose moiety ( $-72 \mathrm{u}$ ), respectively (Du et al., 2012). Compound 27 was tentatively identified as isorhamnetin-O-glucuronide based on its deprotonated ion $(m / z 491)$ and $\mathrm{MS}^{2}$ spectra, releasing fragments corresponding to isorhamnetin $(\mathrm{m} / \mathrm{z} 315)$ and the loss of a glucuronide moiety (-176 u) (Falcão et al., 2013). Compound 7, present in the $C$. hypocistis extract, was identified as $(+)$-Catechin, based on its $\mathrm{MS}^{2}$ pattern, showing two typical ions corresponding to the loss of $\mathrm{CO}_{2}$ (major ion at $m / z 245$ ) and an A-ring of flavan-3-ol (minor ion at $m / z$ 203) (Carocho et al., 2014). Compound $13\left([\mathrm{M}-\mathrm{H}]^{-}\right.$at $\left.m / z 465\right)$ present in the root extracts of the parasited and non-parasited $H$. lasianthum lost a fragment ion $\left.(\mathrm{m} / \mathrm{z} \text { 303; [taxifolin }-\mathrm{H}]^{-}\right)$and a hexosyl moiety $(-162 \mathrm{u}$ ), being identified as taxifolin- $\mathrm{O}$-hexoside (Bastos et al., 2015). Peaks $12,16,20$, and 28 exhibited a UV spectrum and ion fragmentation similar to myricetin glycoside derivatives. These compounds presented a typical MS ${ }^{2}$ fragmentation of an ionised myricetin ( $\left.m / z 317\right)$. Compound $12(\mathrm{~m} / \mathrm{z} 611)$ identified as myricetin 3 - $O$-arabinogalactoside in the PHLAP extract presented a fragment ion at $m / z 317\left([\text { myricetin }-\mathrm{H}]^{-}\right)$; the difference represented the loss of the sugar moiety (arabino-galactose; MW 312). This compound also exhibited a major fragment at $\mathrm{m} / z$ 316; however, $\mathrm{m} / \mathrm{z} 317$ is the fragment consistent with the cleavage into the aglycone myricetin; this anomalous fragmentation pattern has been reported previously for quercetin derivatives (Rodríguez-Medina et al., 2009). The minor ion at $m / z 271$ is characteristic of 3-O-monoglycosides (Gori et al., 2016). Myricetin-O-hexoside (peak 16) and
myricetin-O-rhamnoside (peak 20) were tentatively identified in the non-parasited (HLAP) and parasited (PHLAP) aerial extracts of H. lasianthum, with deprotonated ions $[\mathrm{M}-\mathrm{H}]{ }^{-}$at $\mathrm{m} / \mathrm{z} 479$ and 463 , respectively. Both compounds exhibited two common $\mathrm{MS}^{2}$ fragments of myricetin $(m / z 317$ and 316$)$ after the release of a hexosyl $(-162 \mathrm{u})$ and a rhamnoside ( -146 u) moiety (Bouziane et al., 2018; Gori et al., 2016; Guimarães et al., 2013b, 2013c). Compound 28 showed [M-H] ${ }^{-}$ion at $m / z 771$, and further fragmentation at $m / z 463$ [M-H-308] ${ }^{-}$and $m / z$ $317[(\mathrm{M}-\mathrm{H})-308+146]^{-}$, suggesting the losses of coumaric acid and deoxyhexoside-hexoside groups, and the presence of myricetin (MW 317) (Bouziane et al., 2018). Compounds 21, 22, 25, 26, and 30 showed UV spectra and $\mathrm{MS}^{2}$ fragment at $m / z 301$, typical of quercetin glycoside derivatives. Compound 21 (HLR extract) was identified as querceti$\mathrm{n}$ - $\mathrm{O}$-hexoside by the presence of a pseudo-molecular ion $[\mathrm{M}-\mathrm{H}]^{-}$at $m / z$ 463 and a major fragment at $m / z 301$ (loss of a hexosyl residue) (Barros et al., 2013). Compound 22 (HLR, HLAP, and PHLR extracts) was positively identified as quercetin-3-O-glucoside using a commercial standard. Compound 25 (PHLAP) was assigned as quercetin-O-acetylhexoside ([M-H] - at $m / z 505$ ) according to its deprotonated ion and $\mathrm{MS}^{2}$ spectra, releasing fragments corresponding to the losses of an acetyl residue $(-42 \mathrm{u})$ and a hexosyl moiety $(-162 \mathrm{u})$ (Barros et al., 2013). Quercetin- $O$-pentoside (compound $26 ; \mathrm{m} / z$ 433; HLAP and PHLAP extracts) and quercetin-3-O-rhamnoside (compound 30; $\mathrm{m} / z$ 447; HLAP and PHLAP extracts) were identified using their deprotonated ions and $\mathrm{MS}^{2}$ fragments, consistent with quercetin $(\mathrm{m} / \mathrm{z}$ at 301$)$, and the loss of pentosyl $(-132 \mathrm{u})$ and rhamnosyl $(-146 \mathrm{u})$ moieties, respectively (Guimarães et al., 2013c). Compounds 37, 38, and 39, present in HLAP and PHLAP extracts, exhibited a UV spectrum and a $\mathrm{MS}^{2}$ fragmentation typical of kaempferol glycoside derivatives. Compound 37 was identified as an isomer of an kaempferol-coumaroyl-hexoside by its deprotonated ion $[\mathrm{M}-\mathrm{H}]^{-}$at $m / z 593$, artefact peak $[2 \mathrm{M}-\mathrm{H}]^{-}$at $m / z 1187$, and a $\mathrm{MS}^{2}$ fragment at $m / z 447$ (Simirgiotis et al., 2009). Compounds 38 and 39 (O-rhamnoside- $O$-hexoside and kaempferol-coumaroyl-hexoside, respectively) had a molecular ion $[\mathrm{M}-\mathrm{H}]^{-}$at $m / z 593$ that generated one minor $\mathrm{MS}^{2}$ fragment at $\mathrm{m} / \mathrm{z} 447$ (rhamnose moiety release) and a major at 285 (release of rhamnose and hexose moieties), which is in agreement with kaempferol- $O$-rhamnoside- $O$-hexoside tentative identification (Barros et al., 2013). Kaempferol-coumaroyl-hexoside is also a possible tentative identification for peaks 38 and 39 due to their [M-H $]^{-}$ at $m / z 593$, a MS ${ }^{2}$ minor fragment at $m / z 447$, and a major fragment at $m / z 285$ (loss of 308 u, M-coumaroyl-hexose moiety) (Simirgiotis et al., 2009). The acylation of flavonoids increases their molecular size and changes the spatial structure of the flavonoid aglycone, as it occurs with anthocyanin compounds (Giusti and Wrolstad, 2003). These structural changes decrease the polarity of the entire molecule, increasing their retention time in a reversed-phase column, as used in the present study.

\subsubsection{Hydrolysable tannins}

Gallotannins or galloylated esters of glucose show elimination of multiple galloyl $[\mathrm{M}-\mathrm{H}-152]^{-}$and gallate $[\mathrm{M}-\mathrm{H}-170]^{-}$moieties in $\mathrm{MS}^{\mathrm{n}}$ analysis. Compounds $1\left([\mathrm{M}-\mathrm{H}]^{-}\right.$at $\left.m / z 331\right)$ and $2\left([\mathrm{M}-\mathrm{H}]^{-}\right.$at $\left.m / z 483\right)$ were deduced as galloyl-glucose and digalloyl-glucose, respectively. These $\mathrm{CH}$ compounds exhibited the release of one and two galloyl moieties characterised by $\mathrm{MS}^{2}$ fragments at $m / z 331$ and 169 , and the loss of a glucose moiety ( -162 u) (A. R. A.R. Silva et al., 2020; V. Silva et al., 2020; Tan et al., 2011). Compounds 5 and 10 were tentatively identified as trigalloyl-glucose, exhibiting a $[\mathrm{M}-\mathrm{H}]^{-}$at $m / z 635$ and a characteristic MS ${ }^{2}$ fragment at $m / z 483$, denoting the release of one galloyl group $(-152 \mathrm{u}$ ). Fragment ions at $m / z 465$ and 313 , which are frequently found on the fragmentation pattern of gallotannins (loss of galloyl groups), were also observed (Tan et al., 2011). Compound 3 (HLAP and PHLAP extracts) was tentatively identified as a punicalagin isomer, with a molecular ion $[\mathrm{M}-\mathrm{H}]^{-}$at $m / z 1083$ that yielded a $\mathrm{MS}^{2}$ fragmentation pattern of punicalin $(m / z 781), m / z 721, m / z 601$, and $m / z 575$ (Sentandreu et al., 2013; Teixeira et al., 2021). Compound 4 (PHLAP extract) also exhibited a deprotonated molecular ion at $\mathrm{m} / \mathrm{z}$ 
1083. Still, the $\mathrm{MS}^{2}$ fragmentation pattern was clearly different from that of punicalagin (Table 1 ). The presence of a specific major daughter ion $(\mathrm{m} / \mathrm{z}$ 601) suggested the existence of a gallagyl derivative, most probably an ester (Sentandreu et al., 2013). Compound 8 (HLAP extract) was tentatively identified as digalloyl-gallagyl-hexoside, with a deprotonated ion at $m / z 1085$, denoting the release of two galloyls $[\mathrm{M}-\mathrm{H}-152+152]^{-}$and the presence of a gallagyl-hexose $(\mathrm{m} / \mathrm{z} 781)$. The minor MS ${ }^{2}$ fragment at $m / z 601$ (gallagyl) shows the consistent mass release of a hexose $(-162 \mathrm{u})$ and a water molecule $(-18 \mathrm{u})$ (Sentandreu et al., 2013). Compound 15 (HLAP and CH) was tentatively identified as trigalloyl-HHDP-glucoside, exhibiting a $[\mathrm{M}-\mathrm{H}]^{-}$at $\mathrm{m} / \mathrm{z} 937$ and a characteristic $\mathrm{MS}^{2}$ at $m / z 301$ (ellagic acid). The product ions at $m / z 767$ and 465 are coherent with the release of gallic acid and hexahydroxydiphenoyl (HHDP) + gallic acid (V. A.R. Silva et al., 2020; V. Silva et al., 2020). Isomers 17, 18, and 19 present in the $C$. hypocistis extract were tentatively identified as tetragalloyl-glucoside I, II, and III, respectively. All compounds presented a pseudo-molecular ion at $m / z$ 787 and a representative $\mathrm{MS}^{2}$ fragment at $m / z 635$ (trigalloyl-glucose), coherent with the release of one galloyl group $(-152 \mathrm{u})$. Their product ions at $\mathrm{m} / \mathrm{z}$ of 617 and 465 correspond to the release of a gallate $(-170 \mathrm{u})$ and galloyl $(-152 \mathrm{u})$ moieties, respectively (Owen et al., 2003). Pentagalloyl-glucoside (compound 23; $\mathrm{CH}$ extract) was tentatively identified based on its $[\mathrm{M}-\mathrm{H}]^{-}$at $\mathrm{m} / \mathrm{z} 939$ and fragments at $\mathrm{m} / \mathrm{z}$ 787 and 769, recognised as the release of a galloyl moiety [M-H-152] and a water molecule, respectively. The major fragment $(\mathrm{m} / \mathrm{z} 769)$ experienced then the release of a galloyl and a water molecule, creating $\mathrm{m} / z$ at 617 and 599, respectively (Soong and Barlow, 2005). Compounds 24 and 29, present in the $\mathrm{CH}$ extract, were tentatively identified as galloyl-bis-HHDP-glucose I and II, respectively. Both compounds presented the same deprotonated ion at $\mathrm{m} / \mathrm{z} 935$ and $\mathrm{MS}^{2}$ fragments at $\mathrm{m} / \mathrm{z}$ $783,765,633$, and 301 , possibly due to the release of a galloyl $(-152 u)$, a water molecule $(-18 \mathrm{u})$, and two HHDP moieties $(-301 \mathrm{u})$, respectively (Carocho et al., 2014). Digalloyl-bis-HHDP-glucose I, II, and III (compounds 32, 33, and 34, respectively) and trigalloyl-bis-HHDP-glucose I and II (compounds 35 and 36, respectively) were tentatively identified in the $\mathrm{CH}$ extract. The product ions at $\mathrm{m} / \mathrm{z} 1087$ and 1257 unveil the consecutive release of two and three galloyl moieties, respectively. This, together with a fragmentation pattern like galloyl-bis-HHDP-glucose allowed its identification (Carocho et al., 2014; A. R. A.R. Silva et al., 2020; V. Silva et al., 2020).

Among the five studied extracts, thirty-nine compounds were tentatively identified. Flavonoids were the principal group of phenolic compounds identified in the host extracts, while hydrolysable tannins were the major group in the parasite extract. These results are in accordance with the available data for $C$. hypocistis and the only published study regarding Halimium genus phytochemical profile (Kerbab et al., 2019; A. R. A.R. Silva et al., 2020; V. Silva et al., 2020). Phenolic acids were only identified in the roots of $H$. lasianthum; the highest concentration was found in the non-parasited extract. The highest concentration of flavonoids was observed in the non-parasited $H$. lasianthum aerial parts and the lowest in the parasited $H$. lasianthum roots. $\mathrm{CH}$ extract exhibited the highest concentration of phenolic compounds, followed by HLAP/PHLAP, HLR, and PHLR.

\subsection{Evaluation of the bioactivities}

\subsubsection{Antioxidant activity}

Lipid peroxidation is a sequence of damaging reactions in cell membranes. This autoxidation process is initiated when a reactive species abstracts an $\mathrm{H}$ atom from a polyunsaturated lipid, resulting in a highly reactive lipid radical. This radical will later react with $\mathrm{O}_{2}$ forming a $\mathrm{ROO}^{\bullet}$, a radical that, when not neutralised by antioxidant defences, can propagate the damage in chain reactions. Lipid peroxidation is a widely used research model to identify antioxidants capable of neutralising the chain reactions and the lipid-peroxidation-mediated toxicity, which can originate DNA and proteins damage, among others
(Ferreira et al., 2009; Lü et al., 2010; A. R. A.R. Silva et al., 2020; V. Silva et al., 2020; Sultana et al., 2013). Erythrocytes are a metabolically simplified model because of the absence of important cellular organelles (Gião et al., 2010). During OxHLIA, the hydrophilic radicals arise from AAPH and attack the membranes; this attack will then generate lipophilic radicals through lipid peroxidation. OxHLIA was used to evaluate the antioxidant ability of the extracts to capture radicals and, consequently, retard haemolysis in sheep erythrocytes (Pinela et al., 2017). The TBARS assay is a simple and low-cost method to screen lipid peroxidation. During this assay, malondialdehyde (MDA), a degradation product of polyunsaturated fatty acids (Sus scrofa domesticus brain tissue), reacts with thiobarbituric acid (TBA) and forms a characteristic [MDA-(TBA) 2 ] complex. This pink chromogenic product is produced at high temperatures and spectrophotometrically detected at $532 \mathrm{~nm}$ (Gulcin, 2020). The obtained results for both methods are presented in Table 2. Concerning OxHLIA results, the $\mathrm{CH}$ extract ( $C$. hypocistis) gave the best antioxidant effect, with an $\mathrm{IC}_{50}$ of $7.3 \mu \mathrm{g} \mathrm{mL}^{-1}$. The extracts HLAP ( $\mathrm{IC}_{50}: 18 \mu \mathrm{g} \mathrm{mL}^{-1}$ ) and HLR ( $\mathrm{IC}_{50}: 14 \mu \mathrm{gL}^{-1}$ ), both from the non-parasited $H$. lasianthum, exhibited the second-best results and a similar $\mathrm{IC}_{50}$ to the positive control Trolox ( $\mathrm{IC}_{50}: 21.8 \mu \mathrm{g} \mathrm{mL}^{-1}$ ). The extracts from the parasited $H$. lasianthum were the least antioxidant, exhibiting the highest IC50 (PHLR: $307 \mu \mathrm{g} \mathrm{mL}^{-1}$ and PHLAP: $63 \mu \mathrm{g} \mathrm{mL}^{-1}$ ).

Similarly to OxHLIA, the CH extract displayed the best result during TBARS, with an $\mathrm{IC}_{50}$ of $1.11 \mu \mathrm{g} \mathrm{mL} \mathrm{m}^{-1}$, followed by the non-parasited H. lasianthum roots and aerial extracts, $5.3 \mu \mathrm{g} \mathrm{mL}^{-1}$ and $5.7 \mu \mathrm{g} \mathrm{mL}^{-1}$, respectively. The roots extract of the parasited $H$. lasianthum (PHLR: $9.5 \mu \mathrm{g} \mathrm{mL}^{-1}$ ) and the positive control (Trolox: $9.1 \mu \mathrm{g} \mathrm{mL}^{-1}$ ) presented similar results. For both antioxidant methods, the best result was obtained by $C$. hypocistis, followed by the non-parasited and parasited $H$. lasianthum extracts. In previous work, $C$. hypocistis presented a lower IC $_{50}$ for OxHLIA and TBARS (A. R. A.R. Silva et al., 2020; V. Silva et al., 2020). Harvest time/year and extraction methodologies have been suggested to affect plants phenolic composition and concentration, respectively (Gomes et al., 2013; Mandim et al., 2020b, 2020a). Analysing the available phenolic profiles of $C$. hypocistis, it is possible to observe a decrease/increase in the concentration of certain phenolic compounds present in the extracts (A. R. A.R. Silva et al., 2020; V. Silva et al., 2020; Silva et al., 2021a). Galloyl-bis-HHDP-glucose, for example, is always the major compound identified in the extract, but its extracted concentrations decreased from the sample harvested in 2018-2019 and 2020. These differences might be associated with the use of distinct plant samples and the applied extraction methodology (maceration at room temperature versus $\mathrm{HAE}$ at $46.4^{\circ} \mathrm{C}$ ). Additionally, plant extracts are very complex, containing hundreds or even thousands of individual compounds. This complexity arises from the number of bioactive species present in the extract and their synergistic, additive, or antagonistic properties (Caesar and Cech, 2019). Therefore, the variations in bioactivity results of the present work, when compared with the previous study, might be accountable to the plant extracts particularities mentioned above. Regarding the Halimium genus, this work confirms the good antioxidant activity exhibited by Halimium ethanolic extracts in previous studies (Kerbab et al., 2019; Rebaya et al., 2015).

\subsubsection{Tyrosinase inhibitory activity}

The discovery of potent and safe enzyme inhibitors extracted from natural matrices has received significant consideration because of the abundance of novel molecules in nature and their promising bioactivities. Tyrosinase is a key regulatory copper protein responsible for the biosynthesis of melanin. Besides being a target for the development of depigmenting agents, the involvement of this enzyme in skin-related pathologies, such as hyperpigmentation and melanoma, is currently acknowledged. For decades, medicinal chemistry studies have been aiming to develop skin depigmenting agents relying almost exclusively on in silico and in vitro screening studies performed using mushroom tyrosinase (Mukherjee et al., 2018; A. R. A.R. Silva et al., 2020; V. Silva 
et al., 2020). The concentrations ( $\mu \mathrm{g} \mathrm{mL} \mathrm{m}^{-1}$ ) of extract and kojic acid required to inhibit $50 \%$ of tyrosinase activity were estimated from the slope of the obtained inhibition percentages (Table 2). All hydroethanolic extracts inhibited enzyme activity; $\mathrm{CH}$ exhibited the most significant result $\left(8 \mu \mathrm{mL}^{-1}\right)$, followed by HLAP/PHLR/PHLAP (11, 9, and $9 \mu \mathrm{g} \mathrm{mL}^{-1}$, respectively), and HLR $\left(12 \mu \mathrm{g} \mathrm{mL}{ }^{-1}\right)$. Although using different methods, in the present work, $C$. hypocistis displayed a better $\mathrm{IC}_{50}$ than in a previous publication and a similar result to Maisetta and colleagues (Maisetta et al., 2019; Silva et al., 2020).

\subsubsection{Cytotoxic activity}

Phenolic compounds have shown promising antitumor properties during both in vitro and in vivo studies. The cytotoxic effect of these bioactive ingredients is associated with their effect as oxidative stress modulators, apoptosis inducers, cell proliferation inhibitors, tumour cell cycle blockers, and angiogenesis/metastasis suppressors (Zyad et al., 2018). The results of the cytotoxic activity against the five tested cell lines are presented in Table 2.

Ellipticine showed to be highly effective against the four tumour cell lines; all values were significantly inferior compared with the extracts. Regarding the growth inhibition of the human gastric adenocarcinoma (AGS), the best results were obtained with $\mathrm{CH}\left(20.9 \mu \mathrm{g} \mathrm{mL}{ }^{-1}\right)$ and HLAP $\left(24 \mu \mathrm{gL}^{-1}\right)$ extracts, followed by PHLAP $\left(47.6 \mu \mathrm{g} \mathrm{mL}^{-1}\right)$, and PHLR $\left(53 \mu \mathrm{g} \mathrm{m}^{-1}\right.$ ). No cytotoxic activity (up to $400 \mu \mathrm{g} \mathrm{m}^{-1}$ ) was observed for the HLR extracts. For the human colorectal adenocarcinoma cell line, the two extracts of the parasited $H$. lasianthum exhibited the best results (PHLAP: $41 \mu \mathrm{g} \mathrm{mL}^{-1}$ and PHLR: $44 \mu \mathrm{g} \mathrm{mL}^{-1}$ ), followed by HLR (55 $\left.\mu \mathrm{g} \mathrm{mL}^{-1}\right), \mathrm{CH}\left(64.1 \mu \mathrm{g} \mathrm{mL}^{-1}\right)$, and HLAP $\left(70 \mu \mathrm{gL}^{-1}\right)$. Concerning breast adenocarcinoma (MCF-7) and non-small cell lung cancer (NCIH460), the PHLR extract obtained the lowest $\mathrm{GI}_{50}\left(23.8 \mu \mathrm{g} \mathrm{mL} \mathrm{m}^{-1}\right.$ and $19.2 \mu \mathrm{g} \mathrm{mL}^{-1}$, respectively) and HLAP the highest $\left(175 \mu \mathrm{g} \mathrm{mL}{ }^{-1}\right.$ and $85 \mu \mathrm{g} \mathrm{mL}^{-1}$, respectively). For MCF-7, PHLAP (53 $\mu \mathrm{g} \mathrm{mL}^{-1}$ ) and HLR $\left(50 \mu \mathrm{g} \mathrm{m}^{-1}\right.$ ) presented the second best $\mathrm{GI}_{50}$ values, followed by $\mathrm{CH}$ $\left(90 \mu \mathrm{g} \mathrm{m}^{-1}\right)$. The second best $\mathrm{GI}_{50}$ results for $\mathrm{NCI}-\mathrm{H} 460$ were exhibited by the $\mathrm{CH}\left(50 \mu \mathrm{g} \mathrm{mL}{ }^{-1}\right)$ and HLR $\left(44 \mu \mathrm{g} \mathrm{mL}{ }^{-1}\right)$ extracts, followed by PHLAP $\left(62.4 \mu \mathrm{g} \mathrm{mL}^{-1}\right)$. In absolute terms, the parasited $H$. lasianthum roots extract (PHLR) was the most effective, exhibiting the lowest $\mathrm{GI}_{50}$ for three of the four tumour cell lines. NCI-H460 $\left(\mathrm{GI}_{50}=19.2 \mu \mathrm{g} \mathrm{mL}^{-1}\right)$ was the most susceptible cell line to PHLR.

Although using different cell lines and extracts, in the present study (MCF-7: $90 \mu \mathrm{g} \mathrm{mL}^{-1}$ ) and Magiatis and colleagues' work (MDA-MB-231:
29-50 $\mu \mathrm{g} \mathrm{mL}^{-1}$ ), C. hypocistis presented similar cytotoxic activity against human breast adenocarcinoma (Magiatis et al., 2001). The cytotoxic activity of $C$. hypocistis extracts against MCF-7 and NCI-H460 was also described in previous work (A. R. A.R. Silva et al., 2020; V. Silva et al., 2020)(A. R. A.R. Silva et al., 2020; V. Silva et al., 2020), where its extracts exhibited higher $\mathrm{GI}_{50}\left(117 \mu \mathrm{gL}^{-1}\right.$ and $102 \mu \mathrm{gL}^{-1}$, respectively) compared with the current study $\left(90 \mu \mathrm{gL}^{-1}\right.$ and $49.8 \mu \mathrm{g} \mathrm{mL}{ }^{-1}$, respectively).

Chemotherapy treatment main goal is to target tumour cells without exhibiting toxicity towards normal cells; therefore, selective toxicity must be considered during the discovery of compounds for cancer treatment (Zyad et al., 2018). To determine whether the tested extracts have a toxic effect on normal cells, they were tested against the non-tumoral cell line VERO (kidney epithelial cell line of an African green monkey) up to the maximum concentration of $400 \mu \mathrm{g} \mathrm{mL}^{-1}$. Except for the extract HLAP against MCF-7 and HLR against AGS, all the other extracts exhibited cytotoxic effects against VERO cells at higher concentrations than the optimal $\mathrm{GI}_{50}$ obtained for the tested tumour cell lines. The best result was obtained by the $\mathrm{CH}$ extracts, with a $\mathrm{GI}_{50}$ of $286.2 \mu \mathrm{g} \mathrm{mL}^{-1}$.

\subsubsection{Anti-inflammatory activity}

Inflammation is considered a non-specific immune response aiming at neutralising external agents and repair tissues. Plants have been successfully employed worldwide in traditional medicine to treat inflammation processes within the body. Therefore, there is a constant pursuit for novel and more efficient naturally occurring molecules or their synthetic derivatives as anti-inflammatory agents (Nunes et al., 2020; Silva et al., 2021b). The extracts exhibiting the lowest IC $_{50}$ (Table 2) were $\mathrm{CH}\left(86 \mu \mathrm{g} \mathrm{m}^{-1}\right)$, HLR $\left(76 \mu \mathrm{g} \mathrm{mL}^{-1}\right)$, and PHLR $\left(73 \mu \mathrm{g} \mathrm{mL}^{-1}\right)$, followed by HLAP $\left(243 \mu \mathrm{g} \mathrm{mL}^{-1}\right)$ and PHLAP $\left(223 \mu \mathrm{g} \mathrm{mL}^{-1}\right)$. In the present work, C. hypocistis exhibited an anti-inflammatory $\mathrm{IC}_{50}$ of $86 \mu \mathrm{g} \mathrm{mL}^{-1}$, lower than the $136 \mu \mathrm{g} \mathrm{mL}$ previously obtained (A.R. Silva et al., 2020; V. Silva et al., 2020).

\subsubsection{Antimicrobial activity}

Phenolic compounds are well known plant-based antimicrobials, which eliminate microbes by increasing their membrane permeability, acidifying the $\mathrm{pH}$, and altering efflux pumping. Scientists have been collecting evidence that plant extracts enhance conventional antibiotic and preservative activities, serving as adjuvants and replacements.

Table 2

Antioxidant, enzyme inhibitory, cytotoxic, and anti-inflammatory activities of $C$. hypocistis and $H$. lasianthum extracts.

\begin{tabular}{|c|c|c|c|c|c|c|}
\hline & HLR & HLAP & PHLR & PHLAP & $\mathrm{CH}$ & \multirow{2}{*}{$\begin{array}{c}\text { Positive control } \\
\text { Trolox }\end{array}$} \\
\hline \multicolumn{6}{|c|}{ Antioxidant activity $\left(\mathrm{IC}_{50}, \mu \mathrm{g} \mathrm{mL}^{-1}\right)$} & \\
\hline OxHLIA $(\Delta t=60 \mathrm{~min})$ & $14.0 \pm 0.1^{\mathrm{ab}}$ & $18 \pm 1^{\mathrm{ab}}$ & $307 \pm 12^{\mathrm{d}}$ & $18 \pm 1^{\mathrm{ab}}$ & $7.3 \pm 0.3^{\mathrm{a}}$ & $21.8 \pm 0.2^{\mathrm{b}}$ \\
\hline \multirow[t]{2}{*}{ TBARS } & $5.3 \pm 0.2^{\mathrm{b}}$ & $5.7 \pm 0.1^{\mathrm{b}}$ & $9.5 \pm 0.9^{d}$ & $7.10 \pm 0.01^{\mathrm{c}}$ & $1.11 \pm 0.01^{\mathrm{a}}$ & $9.1 \pm 0.3^{\mathrm{d}}$ \\
\hline & \multicolumn{3}{|c|}{ Enzyme inhibitory activity $\left(\mathrm{IC}_{50}, \mu \mathrm{g} \mathrm{mL}^{-1}\right)$} & & & Kojic acid* \\
\hline \multirow[t]{2}{*}{ Tyrosinase } & $12 \pm 1^{\mathrm{c}}$ & $11 \pm 1^{\mathrm{bc}}$ & $9 \pm 1^{\mathrm{bc}}$ & $9 \pm 2^{\mathrm{bc}}$ & $8 \pm 1^{b}$ & $1.7 \pm 0.2^{\mathrm{a}}$ \\
\hline & \multicolumn{3}{|c|}{ Cytotoxic activity $\left(\mathrm{GI}_{50}, \mu \mathrm{g} \mathrm{mL}^{-1}\right)$} & & & Ellipticine* \\
\hline AGS & $>400$ & $24 \pm 1^{\mathrm{a}}$ & $53 \pm 4^{c}$ & $47.6 \pm 0.8^{\mathrm{b}}$ & $20.9 \pm 0.9^{\mathrm{a}}$ & $1.23 \pm 0.03$ \\
\hline Caco-2 & $55 \pm 1^{\mathrm{b}}$ & $70 \pm 2^{\mathrm{d}}$ & $44 \pm 2^{\mathrm{a}}$ & $41 \pm 1^{\mathrm{a}}$ & $64.1 \pm 0.7^{\mathrm{c}}$ & $1.21 \pm 0.02$ \\
\hline MCF-7 & $50 \pm 1.2^{\mathrm{b}}$ & $175 \pm 8^{\mathrm{d}}$ & $23.8 \pm 0.8^{\mathrm{a}}$ & $53 \pm 2^{\mathrm{b}}$ & $90 \pm 7^{\mathrm{c}}$ & $1.02 \pm 0.02$ \\
\hline NCI-H460 & $44.0 \pm 0.6^{\mathrm{b}}$ & $85 \pm 4^{\mathrm{d}}$ & $19.2 \pm 0.4^{\mathrm{a}}$ & $62.4 \pm 0.5^{c}$ & $50 \pm 3^{b}$ & $1.01 \pm 0.01$ \\
\hline \multirow[t]{2}{*}{ VERO } & $184 \pm 1^{c}$ & $159 \pm 7^{\mathrm{b}}$ & $61 \pm 4^{\mathrm{a}}$ & $163 \pm 11^{\mathrm{b}}$ & $286.2 \pm 0.8^{\mathrm{d}}$ & $1.41 \pm 0.06$ \\
\hline & \multicolumn{3}{|c|}{ Anti-inflammatory activity $\left(\mathrm{IC}_{50}, \mu \mathrm{g} \mathrm{mL}^{-1}\right)$} & & & Dexamethasone* \\
\hline RAW 264.7 & $76 \pm 2^{\mathrm{a}}$ & $243 \pm 14^{b}$ & $73 \pm 4^{\mathrm{a}}$ & $223 \pm 11^{\mathrm{b}}$ & $86 \pm 4^{\mathrm{a}}$ & $6.3 \pm 0.4$ \\
\hline
\end{tabular}

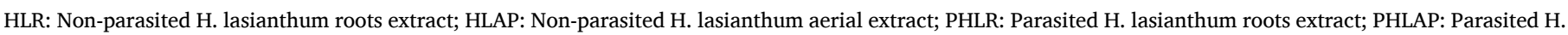

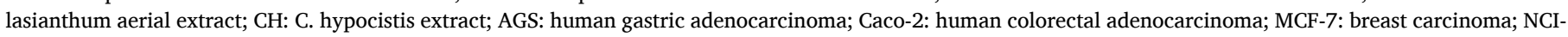

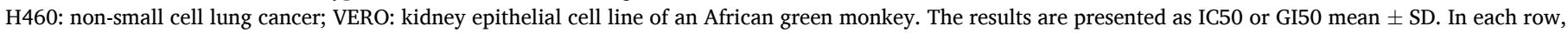

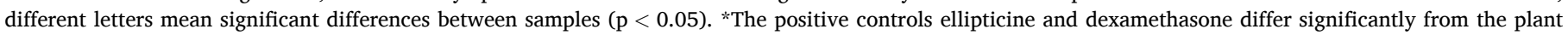
extracts $(\mathrm{p}<0.05)$. 
Table 3

Antimicrobial activity of $C$. hypocistis and $H$. lasianthum extracts $\left(\mathrm{mg} \mathrm{mL}^{-1}\right)$.

\begin{tabular}{|c|c|c|c|c|c|c|c|c|c|c|c|c|c|c|}
\hline & \multicolumn{2}{|c|}{ HLR } & \multicolumn{2}{|c|}{ HLAP } & \multicolumn{2}{|c|}{ PHLR } & \multicolumn{2}{|c|}{ PHLAP } & \multicolumn{2}{|c|}{$\mathrm{CH}$} & \multicolumn{2}{|c|}{ Ampicillin } & \multicolumn{2}{|c|}{ Streptomycin } \\
\hline & MIC & MBC & MIC & MBC & MIC & MBC & MIC & MBC & MIC & MBC & MIC & MBC & MIC & MBC \\
\hline \multicolumn{15}{|l|}{ Gram-positive bacteria } \\
\hline Staphylococcus aureus & 1.00 & 2.00 & 0.50 & 1.00 & 0.50 & 1.00 & 1.00 & 2.00 & 1.00 & 2.00 & 0.25 & 0.45 & 0.04 & 0.10 \\
\hline Bacillus cereus & 0.25 & 0.50 & 0.25 & 0.50 & 0.25 & 0.50 & 0.50 & 1.00 & 0.25 & 0.50 & 0.25 & 0.40 & 0.10 & 0.20 \\
\hline Listeria monocytogenes & 1.00 & 2.00 & 1.00 & 2.00 & 0.50 & 1.00 & 1.00 & 2.00 & 1.00 & 2.00 & 0.40 & 0.50 & 0.20 & 0.30 \\
\hline \multicolumn{15}{|l|}{ Gram-negative bacteria } \\
\hline Escherichia coli & 1.00 & 2.00 & 0.50 & 1.00 & 0.50 & 1.00 & 0.25 & 0.50 & 0.50 & 1.00 & 0.40 & 0.50 & 0.20 & 0.30 \\
\hline Salmonella Typhimurium & 1.00 & 2.00 & 0.50 & 1.00 & 1.00 & 2.00 & 0.50 & 1.00 & 1.00 & 2.00 & 0.75 & 1.20 & 0.20 & 0.30 \\
\hline \multirow[t]{2}{*}{ Enterobacter cloacae } & 1.00 & 2.00 & 1.00 & 2.00 & 0.50 & 1.00 & 1.00 & 2.00 & 1.00 & 2.00 & 0.25 & 0.50 & 0.20 & 0.30 \\
\hline & & & & & & & & & & & \multicolumn{2}{|c|}{ Ketoconazole } & \multicolumn{2}{|c|}{ Bifonazole } \\
\hline Micromycetes & MIC & MFC & MIC & MFC & MIC & MFC & MIC & MFC & MIC & MFC & MIC & MFC & MIC & MFC \\
\hline Aspergillus fumigatus & 0.50 & 1.00 & 0.50 & 1.00 & 0.50 & 1.00 & 0.50 & 1.00 & 0.50 & 1.00 & 0.25 & 0.50 & 0.15 & 0.20 \\
\hline Aspergillus niger & 0.50 & 1.00 & 0.50 & 1.00 & 0.50 & 1.00 & 0.50 & 1.00 & 0.50 & 1.00 & 0.20 & 0.50 & 0.15 & 0.20 \\
\hline Aspergillus versicolor & 0.50 & 1.00 & 0.25 & 0.50 & 0.50 & 1.00 & 0.50 & 1.00 & 0.50 & 1.00 & 0.20 & 0.50 & 0.15 & 0.20 \\
\hline Penicillium funiculosum & 0.50 & 1.00 & 0.25 & 0.50 & 0.25 & 0.50 & 0.50 & 1.00 & 0.50 & 1.00 & 0.20 & 0.50 & 0.20 & 0.25 \\
\hline Penicillium verrucosum var. cyclopium & 0.50 & 1.00 & 0.50 & 1.00 & 0.50 & 1.00 & 0.50 & 1.00 & 0.50 & 1.00 & 0.20 & 0.30 & 0.10 & 0.20 \\
\hline Trichoderma viride & 0.50 & 1.00 & 0.50 & 1.00 & 0.50 & 1.00 & 0.50 & 1.00 & 0.25 & 0.50 & 1.00 & 1.00 & 0.15 & 0.20 \\
\hline
\end{tabular}

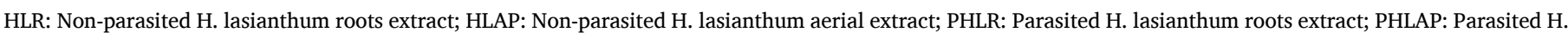

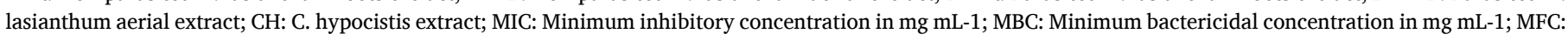
minimal fungicidal concentration; Positive controls: ampicillin, streptomycin, ketoconazole, and bifonazole.

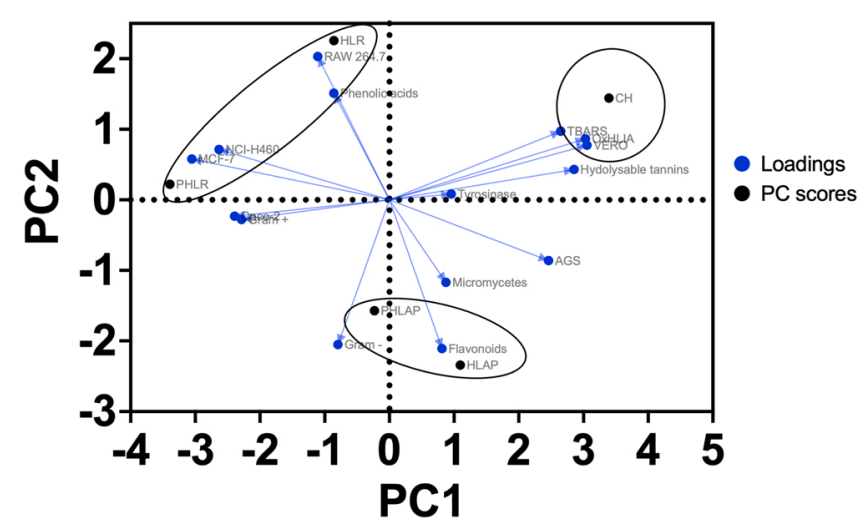

Fig. 2. Biplot of the five hydroethanolic extracts as PC scores and phenolic composition and evaluated bioactivities as loadings.

Accordingly, the search for novel compounds derived from plants has become an emergent area of great interest for the development of combined treatments (Cheesman et al., 2017; Silva et al., 2021b; Srivastava et al., 2014). The five hydroethanolic extracts obtained from C. hypocistis and $H$. lasianthum were assessed for their antibacterial activity (Table 3) against Gram+ and Gram- bacteria. All the tested extracts exhibited antibacterial activity. Streptomycin showed to be the most effective antibiotic; all its MICs and MBCs were inferior to the tested extracts and ampicillin. Both the parasited and non-parasited $H$. lasianthum aerial extracts (PHLAP and HLAP, respectively) presented lower MIC $\left(0.50 \mathrm{mg} \mathrm{mL}^{-1}\right)$ and MBC $\left(1.00 \mathrm{mg} \mathrm{mL}^{-1}\right)$ than the antibiotic ampicillin (MIC: $0.75 \mathrm{mg} \mathrm{mL}^{-1}$; MBC: $1.20 \mathrm{mg} \mathrm{mL}^{-1}$ ) against $S$. Typhimurium. Similarly, the parasited $H$. lasianthum aerial extract (MIC: $0.25 \mathrm{mg} \mathrm{mL}^{-1}$; MBC: $0.50 \mathrm{mg} \mathrm{mL}^{-1}$ ) produced lower MIC and equal MBC than ampicillin (MIC: $0.40 \mathrm{mg} \mathrm{mL}^{-1}$; MBC: $0.50 \mathrm{mg} \mathrm{mL}^{-1}$ ) for E. coli. Concerning B. cereus, two of the tested extracts (CH and HLR) exhibited equal MICs $\left(0.25 \mathrm{mg} \mathrm{mL}^{-1}\right)$ and slightly higher MBC $\left(0.50 \mathrm{mg} \mathrm{mL}^{-1}\right.$ ) than ampicillin (MBC: $0.40 \mathrm{mg} \mathrm{mL}^{-1}$ ). For all the other tested bacteria, ampicillin generated better results. Regarding two of the tested microorganisms (E. coli and L. monocytogenes), $\mathrm{CH}$ extracts exhibited better MICs and MBCs than in a preliminary study (A. R. A.R. Silva et al., 2020; V. Silva et al., 2020).

The antifungal activity of the extracts (Table 3) was tested against five species capable of synthesising toxic metabolites. All the extracts exhibited antifungal activity against the tested micromycetes. Bifonazole showed to be the most effective fungicide; all its MICs and MFCs were inferior to the tested extracts and ketoconazole. The aerial extracts from the non-parasited $H$. lasianthum exhibited identical MFCs $\left(0.50 \mathrm{mg} \mathrm{mL}^{-1}\right)$ than ketoconazole and slightly higher MICs $\left(0.20 \mathrm{mg} \mathrm{mL}^{-1}\right.$ versus $\left.0.25 \mathrm{mg} \mathrm{mL}^{-1}\right)$ against $A$. versicolor and $P$. funiculosum. Similarly, the parasited $H$. lasianthum roots extract (PHLR) showed equal MFC $\left(0.50 \mathrm{mg} \mathrm{mL}^{-1}\right)$ and slightly higher MIC $\left(0.25 \mathrm{mg} \mathrm{mL}^{-1}\right)$ against $P$. funiculosum. C. hypocistis $(\mathrm{CH})$ exhibited better MIC $\left(0.25 \mathrm{mg} \mathrm{mL}^{-1}\right)$ and MFC $\left(0.25 \mathrm{mg} \mathrm{mL}^{-1}\right)$ than the fungicide ketoconazole (MIC and MFC: $1.0 \mathrm{mg} \mathrm{mL}^{-1}$ ) against T. viride.

\subsection{Principal component analysis (PCA)}

PCA was applied to analyse the differences between extracts according to their phenolic composition and bioactivities. The model explained $67 \%$ of the observed variance with the first two principal components (PCs). Score and loading plots on PC2 vs PC1 are shown in Fig. 2. PC1 (Eigenvalue: 6.05; the proportion of total variance: 37.8\%) separates the samples by hydrolysable tannins, OxHLIA, TBARS, AGS, MCF-7, NCI-H460, and VERO. PC2 (Eigenvalue: 4.5; the proportion of total variance: $28.1 \%$ ) separates by flavonoids, RAW 264.7, and Gram-. Analysing Fig. 2, it was possible to distinguish three groups: group 1 containing the extracts from the host roots (HLR and PHLR); group 2 comprising the aerial extracts of the host (HLA and PHLA); and group 3 inclosing $C$. hypocistis extract $(\mathrm{CH})$. The first group was characterised by high anti-inflammatory activity, low flavonoid content, high cytotoxic activity against MCF-7 and NCI-H460, and low cytotoxicity against AGS. The second group was defined by: a high average MIC against Grambacteria, a high flavonoid content, and good cytotoxic activity towards AGS cells. Finally, group 3 was interpreted as having the best antioxidant activity, a high tannin content, and low cytotoxicity against VERO and Caco-2 cells. These results highlight the differences between host and parasite phenolic content and bioactivities.

\section{Conclusions}

To the authors' best knowledge, this report is the first to compare the phenolic profile and the bioactive properties of the parasite $C$. hypocistis and its host $H$. lasianthum. Except for one compound, trigalloyl-HHDPglucoside, the phenolic profile of the host (both non-parasited and parasited) was different from that of the parasite, which possibly 
indicates the existence of a proper pathway of compound biosynthesis in the parasite. This hypothesis is supported by the PCA analysis, where three defined groups were identified: root extracts from $H$. lasianthum, aerial extracts from $H$. lasianthum, and $C$. hypocistis extracts.

Concerning the bioactivities, this is the first work assessing the antioxidant, anti-tyrosinase, antimicrobial, cytotoxic, and antiinflammatory activities of $H$. lasianthum. In absolute terms, the $H$. lasianthum extracts exhibited the best growth inhibition for three of the four tumour cell lines, and C. hypocistis presented the best antioxidant activities.

This novel work revealed differences in the phytochemical components and health-promoting properties of the extracts of $C$. hypocistis and its host species, $H$. lasianthum. These results highlight the importance of these two species as promising sources of functional bioactive ingredients.

\section{CRediT authorship contribution statement}

Ana Rita Silva: Conceptualisation, Methodology, Investigation, Data analysis, Writing. Manuel Ayuso: Methodology, Data analysis, Writing, Reviewing. Carla Pereira: Methodology, Data analysis, Reviewing. Maria Inês Dias: Methodology, Reviewing. Marina Kostić: Methodology. Ricardo C. Calhelha: Methodology, Reviewing. Marina Soković: Conceptualisation, Reviewing. Isabel C.F.R. Ferreira: Conceptualisation, Methodology. Pablo A. García: Writing - review \& editing. Lillian Barros: Conceptualisation, Methodology, Reviewing, Editing. All authors have read and approved the final version of the manuscript for publication.

\section{Declaration of Competing Interest}

The authors declare that they have no known competing financial interests or personal relationships that could have appeared to influence the work reported in this paper.

\section{Data Availability Statement}

All relevant data can be found in the manuscript.

\section{Acknowledgements}

The authors are grateful to the Foundation for Science and Technology (FCT, Portugal) for financial support through national funds FCT/MCTES to CIMO (UIDB/00690/2020). A. R. Silva is grateful to FCT and FSE for her Doctoral Grant (SFRH/BD/145834/2019). L. Barros, C. Pereira, I. Dias, and R. C. Calhelha are grateful to F.C.T. and P.I. for their contracts through the institutional scientific employment programme. The authors are also thankful to the FEDER-Interreg España-Portugal programme for financial support through the project TRANSCoLAB: 0612_TRANS_CO_LAB_2_P and to ERDF through the Regional Operational Program North 2020, within the scope of the Project GreenHealth - Norte-01-0145-FEDER-000042. This research was also funded by the Serbian Ministry of Education, Science and Technological Development (Contract No. 451-03-9/2021-14/200007).

\section{References}

Ayuso, M., Pinela, J., Dias, M.I., Barros, L., Ivanov, M., Calhelha, R.C., Soković, M., Ramil-Rego, P., Barreal, M.E., Gallego, P.P., Ferreira, I.C.F.R., 2020. Phenolic composition and biological activities of the in vitro cultured endangered Eryngium viviparum J. Gay. Ind. Crops Prod. 148, 112325 https://doi.org/10.1016/j. indcrop.2020.112325.

Barros, L., Alves, C.T., Dueñas, M., Silva, S., Oliveira, R., Carvalho, A.M., Henriques, M., Santos-Buelga, C., Ferreira, I.C.F.R., 2013. Characterization of phenolic compounds in wild medicinal flowers from Portugal by HPLC-DAD-ESI/MS and evaluation of antifungal properties. Ind. Crops Prod. 44, 104-110. https://doi.org/10.1016/j. indcrop.2012.11.003.
Bastos, C., Barros, L., Dueñas, M., Calhelha, R.C., Queiroz, M.J.R.P., Santos-Buelga, C., Ferreira, I.C.F.R., 2015. Chemical characterisation and bioactive properties of Prunus avium L.: The widely studied fruits and the unexplored stems. Food Chem. 173, 1045-1053. https://doi.org/10.1016/j.foodchem.2014.10.145.

Bessada, S.M.F., Barreira, J.C.M., Barros, L., Ferreira, I.C.F.R., Oliveira, M.B.P.P., 2016. Phenolic profile and antioxidant activity of Coleostephus myconis (L.) Rchb.f.: An underexploited and highly disseminated species. Ind. Crops Prod. 89, 45-51. https:// doi.org/10.1016/j.indcrop.2016.04.065.

Bouman, F., Meijer, W., 1994. Comparative structure of ovules and seeds in Rafflesiaceae. Plant Syst. Evol. 193, 187-212. https://doi.org/10.1007/ BF00983550.

Bouziane, A., Bakchiche, B., Dias, M., Barros, L., Ferreira, I., AlSalamat, H., Bardaweel, S., 2018. Phenolic Compounds and Bioactivity of Cytisus villosus Pourr. Molecules 23, 1994. https://doi.org/10.3390/molecules23081994.

Caesar, L.K., Cech, N.B., 2019. Synergy and antagonism in natural product extracts: when $1+1$ does not equal 2. Nat. Prod. Rep. 36, 869-888. https://doi.org/10.1039/ C9NP00011A.

Carocho, M., Barros, L., Bento, A., Santos-Buelga, C., Morales, P., Ferreira, I.C.F.R., 2014. Castanea sativa Mill. Flowers amongst the Most Powerful Antioxidant Matrices: A Phytochemical Approach in Decoctions and Infusions. Biomed. Res. Int. 2014, 1-7. https://doi.org/10.1155/2014/232956.

Cheesman, M.J., Ilanko, A., Blonk, B., Cock, I.E., 2017. Developing new antimicrobial therapies: Are synergistic combinations of plant extracts/compounds with conventional antibiotics the solution? Pharmacogn. Rev. 11, 57-72. https://doi.org/ 10.4103/phrev.phrev_21_17.

Chihoub, W., Dias, M.I., Barros, L., Calhelha, R.C., Alves, M.J., Harzallah-Skhiri, F., Ferreira, I.C.F.R., 2019. Valorisation of the green waste parts from turnip, radish and wild cardoon: Nutritional value, phenolic profile and bioactivity evaluation. Food Res. Int. 126, 108651 https://doi.org/10.1016/j.foodres.2019.108651.

de Vega, C., Berjano, R., Arista, M., Ortiz, P.L., Talavera, S., Stuessy, T.F., 2008. Genetic races associated with the genera and sections of host species in the holoparasitic plant Cytinus (Cytinaceae) in the Western Mediterranean basin. N. Phytol. 178, 875-887. https://doi.org/10.1111/j.1469-8137.2008.02423.x.

De Vega, C., Ortiz, P.L., Arista, M., Talavera, S., 2007. The endophytic system of Mediterranean Cytinus (Cytinaceae) developing on five host Cistaceae species. Ann. Bot. 100, 1209-1217. https://doi.org/10.1093/aob/mcm217.

Du, X.-G., Wang, W., Zhang, Q.-Y., Cheng, J., Avula, B., Khan, I.A., Guo, D.-A., 2012. Identification of xanthones from Swertia punicea using high-performance liquid chromatography coupled with electrospray ionization tandem mass spectrometry. Rapid Commun. Mass Spectrom. 26, 2913-2923. https://doi.org/10.1002/ RCM.6419.

Falcão, S.I., Vale, N., Gomes, P., Domingues, M.R.M., Freire, C., Cardoso, S.M., VilasBoas, M., 2013. Phenolic Profiling of Portuguese Propolis by LC-MS Spectrometry: Uncommon Propolis Rich in Flavonoid Glycosides. Phytochem. Anal. 24, 309-318. https://doi.org/10.1002/pca.2412.

Ferreira, I.C.F.R., Barros, L., Abreu, R.M.V., 2009. Antioxidants in Wild Mushrooms. Curr. Med. Chem. 16, 1543-1560. https://doi.org/10.2174/092986709787909587.

García-Pérez, P., Ayuso, M., Lozano-Milo, E., Pereira, C., Dias, M.I., Ivanov, M., Calhelha, R.C., Soković, M., Ferreira, I.C.F.R., Barros, L., Gallego, P.P., 2021. Phenolic profiling and in vitro bioactivities of three medicinal Bryophyllum plants. Ind. Crops Prod. 162, 113241 https://doi.org/10.1016/j.indcrop.2021.113241.

Gião, M.S., Leitão, I., Pereira, A., Borges, A.B., Guedes, C.J., Fernandes, J.C., Belo, L., Santos-Silva, A., Hogg, T.A., Pintado, M.E., Malcata, F.X., 2010. Plant aqueous extracts: Antioxidant capacity via haemolysis and bacteriophage P22 protection. Food Control 21, 633-638. https://doi.org/10.1016/j.foodcont.2009.08.014.

Giusti, M.M., Wrolstad, R.E., 2003. Acylated anthocyanins from edible sources and their applications in food systems. Biochem. Eng. J. 14, 217-225. https://doi.org/ 10.1016/S1369-703X(02)00221-8.

Gomes, T., Delgado, T., Ferreira, A., Pereira, J.A., Baptista, P., Casal, S., Ramalhosa, E., 2013. Application of response surface methodology for obtaining lettuce (Lactuca sativa L.) by-products extracts with high antioxidative properties. Ind. Crops Prod. 44, 622-629. https://doi.org/10.1016/j.indcrop.2012.09.011.

Gori, A., Ferrini, F., Marzano, M., Tattini, M., Centritto, M., Baratto, M., Pogni, R., Brunetti, C., 2016. Characterisation and Antioxidant Activity of Crude Extract and Polyphenolic Rich Fractions from C. incanus Leaves. Int. J. Mol. Sci. 17, 1344. https://doi.org/10.3390/ijms17081344.

Guimarães, R., Barros, L., Dueñas, M., Calhelha, R.C., Carvalho, A.M., Santos-Buelga, C., Queiroz, M.J.R.P., Ferreira, I.C.F.R., 2013a. Nutrients, phytochemicals and bioactivity of wild Roman chamomile: A comparison between the herb and its preparations. Food Chem. 136, 718-725. https://doi.org/10.1016/j. foodchem.2012.08.025.

Guimarães, R., Barros, L., Dueñas, M., Calhelha, R.C., Carvalho, A.M., Santos-Buelga, C., Queiroz, M.J.R.P., Ferreira, I.C.F.R., 2013b. Infusion and decoction of wild German chamomile: Bioactivity and characterization of organic acids and phenolic compounds. Food Chem. 136, 947-954. https://doi.org/10.1016/j. foodchem.2012.09.007.

Guimarães, R., Barros, L., Dueñas, M., Carvalho, A.M., Queiroz, M.J.R.P., SantosBuelga, C., Ferreira, I.C.F.R., 2013c. Characterisation of phenolic compounds in wild fruits from Northeastern Portugal. Food Chem. 141, 3721-3730. https://doi.org/ 10.1016/J.FOODCHEM.2013.06.071.

Gulcin, I.., 2020. Antioxidants and antioxidant methods: an updated overview. Arch Toxicol. 94, 651-715. https://doi.org/10.1007/s00204-020-02689-3.

Heffels, P., Müller, L., Schieber, A., Weber, F., 2017. Profiling of iridoid glycosides in Vaccinium species by UHPLC-MS. Food Res. Int. 100, 462-468. https://doi.org/ 10.1016/j.foodres.2016.11.018. 
Heleno, S.A., Ferreira, I.C.F.R., Esteves, A.P., Ćirić, A., Glamočlija, J., Martins, A., Soković, M., Queiroz, M.J.R.P., 2013. Antimicrobial and demelanizing activity of Ganoderma lucidum extract, p-hydroxybenzoic and cinnamic acids and their synthetic acetylated glucuronide methyl esters. Food Chem. Toxicol. 58, 95-100. https://doi.org/10.1016/j.fct.2013.04.025.

Kerbab, K., Sansone, F., Zaiter, L., Esposito, T., Celano, R., Franceschelli, S., Pecoraro, M., Benayache, F., Rastrelli, L., Picerno, P., Aquino, R.P., Mencherini, T., 2019. Halimium halimifolium: From the Chemical and Functional Characterization to a Nutraceutical Ingredient Design. Planta Med 85, 1024-1033. https://doi.org/ 10.1055/a-0953-6007.

Leonardi, M., Furtado, A.N.M., Comandini, O., Geml, J., Rinaldi, A.C., 2020. Halimium as an ectomycorrhizal symbiont: new records and an appreciation of known fungal diversity. Mycol. Prog. 19, 1495-1509. https://doi.org/10.1007/s11557-02001641-0.

Lockowandt, L., Pinela, J., Roriz, C.L., Pereira, C., Abreu, R.M.V., Calhelha, R.C., Alves, M.J., Barros, L., Bredol, M., Ferreira, I.C.F.R., 2019. Chemical features and bioactivities of cornflower (Centaurea cyanus L.) capitula: The blue flowers and the unexplored non-edible part. Ind. Crops Prod. 128, 496-503. https://doi.org/ 10.1016/J.INDCROP.2018.11.059.

Lü, J.-M., Lin, P.H., Yao, Q., Chen, C., 2010. Chemical and molecular mechanisms of antioxidants: experimental approaches and model systems. J. Cell. Mol. Med 14, 840-860. https://doi.org/10.1111/j.1582-4934.2009.00897.x.

Magiatis, P., Pratsinis, H., Kalpoutzakis, E., Konstantinidou, A., Davaris, P., Skaltsounis, A.-L., 2001. Hydrolyzable Tannins, the Active Constituents of Three Greek Cytinus Taxa against Several Tumor Cell Lines. Biol. Pharm. Bull. 24, 707-709. https://doi.org/10.1248/bpb.24.707.

Maisetta, G., Batoni, G., Caboni, P., Esin, S., Rinaldi, A.C., Zucca, P., 2019. Tannin profile, antioxidant properties, and antimicrobial activity of extracts from two Mediterranean species of parasitic plant Cytinus. BMC Complement. Altern. Med. 19, 82. https://doi.org/10.1186/s12906-019-2487-7.

Mandim, F., Petropoulos, S.A., Fernandes, Â., Santos-Buelga, C., Ferreira, I.C.F.R., Barros, L., 2020a. Chemical Composition of Cynara cardunculus L. var. altilis Heads: The Impact of Harvesting Time. Agronomy 10, 1088. https://doi.org/10.3390/ agronomy 10081088.

Mandim, F., Petropoulos, S.A., Giannoulis, K.D., Dias, M.I., Fernandes, Â., Pinela, J., Kostic, M., Soković, M., Barros, L., Santos-Buelga, C., Ferreira, I.C.F.R., 2020 b. Seasonal variation of bioactive properties and phenolic composition of Cynara cardunculus var. altilis. Food Res. Int. 134, 109281 https://doi.org/10.1016/j. foodres.2020.109281.

Moonrungsee, N., Shimamura, T., Kashiwagi, T., Jakmunee, J., Higuchi, K., Ukeda, H., 2012. Sequential injection spectrophotometric system for evaluation of mushroom tyrosinase-inhibitory activity. Talanta 101, 233-239. https://doi.org/10.1016/j. talanta.2012.09.015.

Mukherjee, P.K., Biswas, R., Sharma, A., Banerjee, S., Biswas, S., Katiyar, C.K., 2018. Validation of medicinal herbs for anti-tyrosinase potential. J. Herb. Med. 14, 1-16. https://doi.org/10.1016/j.hermed.2018.09.002.

Nunes, C., dos, R., Barreto Arantes, M., Menezes de Faria Pereira, S., Leandro da Cruz, L., de Souza Passos, M., Pereira de Moraes, L., Vieira, I.J.C., Barros de Oliveira, D., 2020. Plants as Sources of Anti-Inflammatory Agents. Molecules 25, 3726. https:// doi.org/10.3390/molecules25163726.

Owen, R.W., Haubner, R., Hull, W.E., Erben, G., Spiegelhalder, B., Bartsch, H., Haber, B., 2003. Isolation and structure elucidation of the major individual polyphenols in carob fibre. Food Chem. Toxicol. 41, 1727-1738. https://doi.org/10.1016/S02786915(03)00200-X.

Pantuzza Silva, G.F., Pereira, E., Melgar, B., Stojković, D., Sokovic, M., Calhelha, R.C., Pereira, C., Abreu, R.M.V., Ferreira, I.C.F.R., Barros, L., 2021. Eggplant fruit (Solanum melongena 1.) and bio-residues as a source of nutrients, bioactive compounds, and food colorants, using innovative food technologies. Appl. Sci. 11, 1-24. https://doi.org/10.3390/app11010151.

Pinela, J., Prieto, M.A., Barreiro, M.F., Carvalho, A.M., Oliveira, M.B.P.P., Curran, T.P., Ferreira, I.C.F.R., 2017. Valorisation of tomato wastes for development of nutrientrich antioxidant ingredients: A sustainable approach towards the needs of the today's society. Innov. Food Sci. Emerg. Technol. 41, 160-171. https://doi.org/ 10.1016/j.ifset.2017.02.004.

Rebaya, A., Belghith, S.I., Baghdikian, B., Leddet, V.M., Mabrouki, F., Olivier, E., Cherif, J.K., Ayadi, M.T., 2015. Total Phenolic, Total Flavonoid, Tannin Content, and Antioxidant Capacity of Halimium halimifolium (Cistaceae). J. Appl. Pharm. Sci. 5, 052-057. https://doi.org/10.7324/JAPS.2015.50110.

Rodríguez-Medina, I.C., Beltrán-Debón, R., Molina, V.M., Alonso-Villaverde, C., Joven, J., Menéndez, J.A., Segura-Carretero, A., Fernández-Gutiérrez, A., 2009. Direct characterization of aqueous extract of Hibiscus sabdariffa using HPLC with diode array detection coupled to ESI and ion trap MS. J. Sep. Sci. 32, 3441-3448. https://doi.org/10.1002/jssc.200900298.

Rubiales, D., Heide-Jørgensen, H.S., 2011. Parasitic Plants. In: Encyclopedia of Life Sciences. John Wiley \& Sons, Ltd, Chichester, UK. https://doi.org/10.1002/ 9780470015902.a0021271.

Sanjust, E., Rinaldi, A.C., 2021. Cytinus under the Microscope: Disclosing the Secrets of a Parasitic Plant. Plants 10, 146. https://doi.org/10.3390/plants10010146.

Sentandreu, E., Cerdán-Calero, M., Sendra, J.M., 2013. Phenolic profile characterization of pomegranate (Punica granatum) juice by high-performance liquid chromatography with diode array detection coupled to an electrospray ion trap mass analyzer. J. Food Compos. Anal. 30, 32-40. https://doi.org/10.1016/j. jfca.2013.01.003.

Silva, A.R., Fernandes, Â., García, P.A., Barros, L., Ferreira, I.C.F.R., 2019. Cytinus hypocistis (L.) L. subsp. macranthus Wettst.: Nutritional Characterization. Molecules 24, 1111. https://doi.org/10.3390/molecules24061111.

Silva, A.R., Pinela, J., Dias, M.I., Calhelha, R.C., Alves, M.J., Mocan, A., García, P.A., Barros, L., Ferreira, I.C.F.R., 2020. Exploring the phytochemical profile of Cytinus hypocistis (L.) L. as a source of health-promoting biomolecules behind its in vitro bioactive and enzyme inhibitory properties. Food Chem. Toxicol. 136, 111071 https://doi.org/10.1016/j.fct.2019.111071.

Silva, A.R., Pinela, J., García, P.A., Ferreira, I.C.F.R., Barros, L., 2021a. Cytinus hypocistis (L.) L.: Optimised heat/ultrasound-assisted extraction of tannins by response surface methodology. Sep. Purif. Technol. 276, 119358 https://doi.org/10.1016/j. seppur.2021.119358.

Silva, A.R., Taofiq, O., Ferreira, I.C.F.R., Barros, L., 2021b. Hypericum genus cosmeceutical application - A decade comprehensive review on its multifunctional biological properties. Ind. Crops Prod. 159. https://doi.org/10.1016/j. indcrop.2020.113053.

Silva, V., Falco, V., Dias, M.I., Barros, L., Silva, A., Capita, R., Alonso-Calleja, C., Amaral, J.S., Igrejas, G., Ferreira, I.C.F.R., Poeta, P., 2020. Evaluation of the Phenolic Profile of Castanea sativa Mill. By-Products and Their Antioxidant and Antimicrobial Activity against Multiresistant Bacteria. Antioxidants 9, 87. https:// doi.org/10.3390/ANTIOX9010087.

Simirgiotis, M.J., Theoduloz, C., Caligari, P.D.S., Schmeda-Hirschmann, G., 2009. Comparison of phenolic composition and antioxidant properties of two native Chilean and one domestic strawberry genotypes. Food Chem. 113, 377-385. https:// doi.org/10.1016/j.foodchem.2008.07.043.

Smith, J.D., Mescher, M.C., De Moraes, C.M., 2013. Implications of bioactive solute transfer from hosts to parasitic plants. Curr. Opin. Plant Biol. 16, 464-472. https:// doi.org/10.1016/j.pbi.2013.06.016.

Soong, Y.Y., Barlow, P.J., 2005. Isolation and structure elucidation of phenolic compounds from longan (Dimocarpus longan Lour.) seed by high-performance liquid chromatography- electrospray ionization mass spectrometry. J. Chromatogr. A 1085, 270-277. https://doi.org/10.1016/j.chroma.2005.06.042.

Souilem, F., Fernandes, Â., Calhelha, R.C., Barreira, J.C.M., Barros, L., Skhiri, F., Martins, A., Ferreira, I.C.F.R., 2017. Wild mushrooms and their mycelia as sources of bioactive compounds: Antioxidant, anti-inflammatory and cytotoxic properties. Food Chem. 230, 40-48. https://doi.org/10.1016/j.foodchem.2017.03.026.

Srivastava, J., Chandra, H., Nautiyal, A.R., Kalra, S.J.S., 2014. Antimicrobial resistance (AMR) and plant-derived antimicrobials (PDAms) as an alternative drug line to control infections. 3 Biotech 4, 451-460. https://doi.org/10.1007/s13205-0130180-y.

Sultana, R., Perluigi, M., Butterfield, D.A., 2013. Lipid peroxidation triggers neurodegeneration: A redox proteomics view into the Alzheimer disease brain. Free Radic. Biol. Med. 62, 157-169. https://doi.org/10.1016/j. freeradbiomed.2012.09.027.

Tan, H.P., Ling, S.K., Chuah, C.H., 2011. Characterisation of galloylated cyanogenic glucosides and hydrolysable tannins from leaves of Phyllagathis rotundifolia by LCESI-MS/MS. Phytochem. Anal. 22, 516-525. https://doi.org/10.1002/pca.1312.

Teixeira, N., Nabais, P., de Freitas, V., Lopes, J.A., Melo, M.J., 2021. In-depth phenolic characterization of iron gall inks by deconstructing representative Iberian recipes. Sci. Rep. 11, 8811. https://doi.org/10.1038/s41598-021-87969-3.

Westwood, J.H., Yoder, J.I., Timko, M.P., dePamphilis, C.W., 2010. The evolution of parasitism in plants. Trends Plant Sci. 15, 227-235. https://doi.org/10.1016/j. tplants.2010.01.004.

Zucca, P., Pintus, M., Manzo, G., Nieddu, M., Steri, D., Rinaldi, A.C., 2015. Antimicrobial, antioxidant and anti-tyrosinase properties of extracts of the Mediterranean parasitic plant Cytinus hypocistis. BMC Res. Notes 8, 562. https://doi.org/10.1186/s13104015-1546-5.

Zyad, A., Leouifoudi, I., Tilaoui, M., Mouse, H.A., Khouchani, M., Jaafari, A., 2018. Natural Products as Cytotoxic Agents in Chemotherapy against Cancer, in: Cytotoxicity. InTech. https://doi.org/10.5772/intechopen.72744. 